\title{
NSU CASE COVERED UP AND LEGALLY CLOSED: IS IT POSSIBLE TO AVOID SOCIAL AND POLITICAL REPERCUSSIONS?
}

\section{Teoman Ertuğrul TULUN}

\section{Analyst}

As detailed information was given in our two AVIM analyses, the neo-Nazi Nationalist Socialist Underground (NSU) terrorist group killed ten people in Germany between 20002007. Eight of the victims were members of the Turkish community of more than three million people living in Germany.[1]

As will be remembered, Beate Zschäpe, Uwe Mundlos, and Uwe Böhnhardt were the nucleus of the National Socialist Underground NSU). Two of them, Uwe Mundlos and Uwe Böhnhardt, had killed themselves in the operations. Beate Zschäpe was the only core member of the NSU who stayed alive when the NSU trial began on 6 May 2013 in the 6th Criminal Division of Munich's Higher Regional Court. Along with Beate Zschäpe, the four suspected accomplices deemed to be in the close periphery of the NSU trio, including Ralf Wohlleben and André Eminger, were tried. Zschäpe was accused of ten murders, arson, forming a terrorist organization, and membership in a terrorist organization. Ralf Wohlleben, a former official of the far-right German National Democratic Party (NPD), was detained on 29 November 2011 and charged with supporting a terrorist organization and complicity in six murders. The experts consider André Eminger on the NSU as a member of the NSUs close periphery. After nearly a five-year trial, the Munich Higher Regional Court issued the verdict on 11 June 2018. Beate Zschäpe was found to be complicit in ten murders, forty-three attempted murders, two severe bombing attacks, fifteen banks, and other robberies, and sentenced to life in prison. Ralf Wohlleben was sentenced to ten years for aiding and abetting murder. Carsten Schultze, a juvenile at the time, was found guilty of handing the pistol and silencer to the NSU and was sentenced to three years. Holger Gerlach received three years sentence for giving his birth certificate and other ID to NSU member Uwe Mundlos. André Eminger was given only two years and six months for helping a terrorist group and was released, having already served his prison time 
during the trial.[2]

Germanys highest court of appeals, the Federal Court of Justice, had rejected appeals by Beate Zschäpe and two other convicted accomplices on 19 August 2021. According to press reports, Germany's Federal Court of Justice, this time, on 15 December 2021, dismissed the appeals of both Andre Eminger and prosecutors who challenged his acquittal of other charges, including attempted murder. Thus the Federal Court upheld the exceptionally light prison sentence of two and a half years that Andre Eminger received in 2018 for supporting the terrorist organization. The Munich court's verdict has become fully legally binding through this decision. It is reported that the high court did not find any legal errors or gaps in the arguments of the Munich court for the verdict and rejected both appeals. In this context, it is also reported that the detailed written justification for the final judgment is expected to be published in January 2022.[3]

Ten years after the NSU Neo-Nazi terror cell was exposed, with this decision of the German Federal Court of Justice, the NSU case was legally concluded and closed in its entirety. It is possible to say that this court's last decision contributed to the fact that the nature of the serial murders committed by a racist gang could not be fully elucidated. In addition, it is a fact that the decision did not ease the conscience of the families of victims, 80 percent of whom were members of the Turkish community and damaged the trust in the judiciary.[4]

In our last analysis (footnote two below) on the subject, we emphasized that apart from racism and xenophobia, Islamophobia is on the rise in Germany and that we, as AVIM, consider this fact a worrying development. We also drew attention to the point that the combination of racism and xenophobia brings to the fore the concept of xeno-racism, and this new terminology encompasses anti-Muslim racism/Islamophobia. Finally, we should underline that the totality of court decisions regarding the NSU murders reinforced the perception that racism, xenophobia, and Islamophobia did not receive the punishment they deserved in Germany and that the true dimensions of the NSU organization wilfully be left unclarified. It is worth emphasizing that this inconclusive result in the legal context requires more efforts in the political and social arena to reveal the true motives of the perpetrators of these murders. In this regard, non-governmental organizations have essential duties. From this point of view, it would be misleading to consider that court decisions settled the issue.

*Photo: EoreignPolicy.com 
[1] Teoman Ertuğrul Tulun, Far-Right Violence And Terrorism Rises In Germany: National Socialist Underground (NSU) Terrorist Group And The Murders Of Eight Turkish-German Citizens, Center For Eurasian Studies Analysis Series 2019, no. 20 (August 26, 2019): 8, https://doi.org/10.31219/osf.io/6pf75 , https://avim.org.tr/en/Analiz/FAR-RIGHT-VIOLENCFAND-TERRORISM-RISES-IN-GERMANY-NATIONAL-SOCIALIST-UNDERGROUND-NSUIERRORIST-GROUP-AND-THE-MURDERS-OF-EIGHT-TURKISH-GERMAN-CITIZENS-1.

[2] Teoman Ertuğrul Tulun, Germanys Far-Right Terrorism And The Timid NSU Case Verdict, Center For Eurasian Studies Analysis Series 2020, no. 26 (September 25, 2020): 10, https://doi.org/10.31219/osf.io/s5jm8 , https://avim.org.tr/en/Analiz/GERMANY-S-FARRIGHT-TERRORISM-AND-THE-TIMID-NSU-CASE-VERDICT .

[3] Urteil gegen NSU-Helfer ist rechtskräftig, Tagesschau, December 15, 2021, sec. Innenpolitik, https:/www.tagesschau.de/inland/innenpolitik/revisionsurteil-andree-nsu103.html.

[4] Republic of Turkey Ministry of Foreign Afairs, QA-49, 16 December 2021, Statement of the Spokesperson of the MFA, Ambassador Tanju Bilgiç in Response to a Question Regarding the Decision Taken by the German Federal Court of Appeal in the Context of the NSU Case (Republic of Turkey Ministry of Foreign Afairs, December 16, 2021), QA-49, https://www.mfa.gov.tr/sc_-49_-almanya-federal-yargitayi-nin-nsu-davasinda-aldigi-kararhk-sc.en.mfa.

About the Author:

Teoman Ertuğrul Tulun is an analyst at Ankara-based think-tank Center for Eurasian Studies. He is a PhD Candidate at Bilkent University Department of Political Science and Public Administration. His area of research include European Union Studies, Social Movements, Xenophobia and Hate Speech Studies and State Building Studies.

To cite this article: TULUN, Teoman Ertuğrul. 2021. "NSU CASE COVERED UP AND LEGALLY CLOSED: IS IT POSSIBLE TO AVOID SOCIAL AND POLITICAL REPERCUSSIONS?." Center For Eurasian Studies (AVIM), Commentary No.2021 / 75. December 20. Accessed December 20, 2021. https://avim.org.tr/en/Yorum/NSU-CASE-COVERED-UP-AND-LEGALLY-CLOSED-IS-IT-POSSIBLE-TOAVOID-SOCIAL-AND-POLITICAL-REPERCUSSIONS

\section{(2) AViM}

Süleyman Nazif Sok. No: 12/B Daire 3-4 06550 Çankaya-ANKARA / TÜRKIYE

Tel: +90 (312) 43850 23-24 • Fax: +90 (312) 4385026

@ @avimorgtr

7 https://www.facebook.com/avrasyaincelemelerimerkezi 
E-Mail: info@avim.org.tr

http://avim.org.tr

(C) 2009-2021 Center for Eurasian Studies (AVIM) All Rights Reserved 